\title{
Oxidative stress and hepatitis C virus
}

\author{
Usman Zafar Paracha' ${ }^{1}$ Kaneez Fatima ${ }^{2}$, Mohammad Alqahtani $^{3}$, Adeel Chaudhary ${ }^{3,5}$, Adel Abuzenadah ${ }^{4,5}$, \\ Ghazi Damanhouri ${ }^{5}$ and Ishtiaq Qadri ${ }^{*}$
}

\begin{abstract}
The disproportionate imbalance between the systemic manifestation of reactive oxygen species and body's ability to detoxify the reactive intermediates is referred to as oxidative stress. Several biological processes as well as infectious agents, physiological or environmental stress, and perturbed antioxidant response can promote oxidative stress. Oxidative stress usually happens when cells are exposed to more electrically charged reactive oxygen species (ROS) such as $\mathrm{H}_{2} \mathrm{O} 2$ or O2-. The cells' ability to handle such pro-oxidant species is impeded by viral infections particularly within liver that plays an important role in metabolism and detoxification of harmful substances. During liver diseases (such as hepatocellular or cholestatic problems), the produced ROS are involved in transcriptional activation of a large number of cytokines and growth factors, and continued production of ROS and Reactive Nitrogen Species (RNS) feed into the vicious cycle. Many human viruses like HCV are evolved to manipulate this delicate pro- and antioxidant balance; thus generating the sustainable oxidative stress that not only causes hepatic damage but also stimulates the processes to reduce treatment of damage. In this review article, the oxidant and antioxidant pathways that are perturbed by HCV genes are discussed. In the first line of risk, the pathways of lipid metabolism present a clear danger in accumulation of viral induced ROS. Viral infection leads to decrease in cellular concentrations of glutathione (GSH) resulting in oxidation of important components of cells such as proteins, DNA and lipids as well as double strand breakage of DNA. These disorders have the tendency to lead the cells toward cirrhosis and hepatocellular carcinoma in adults due to constant insult. We have highlighted the importance of such pathways and revealed differences in the extent of oxidative stress caused by HCV infection.
\end{abstract}

Keywords: Oxidative stress, ROS, HCV

\section{Background}

In biological system, the oxidative stress refers to the physiological disturbance between the $\mathrm{ROS}$ such as $\mathrm{H} 2 \mathrm{O} 2$ or O2- and the ability of the body to remove them. Oxidative stress also promotes nitrosative stress caused by reactive nitrogen species resulting in perturbed cellular signaling and cellular damage. Some of the viral infections such as HCV infections decrease the cell's ability to work against such pro-oxidant species especially in liver [1]. Oxidative stress can also be defined as the disordered redox signaling and control [2].

A variety of ROS are produced throughout the body, which are found to be the by-products of cellular metabolism, and play an important role in cell signaling and regulation of cytokine, growth factor and hormone

\footnotetext{
*Correspondence: ishtiaq80262@yahoo.com

${ }^{5}$ King Fahd Medical Research Center, King Abdul Aziz University, PO Box 80216, Jeddah 21589, Saudi Arabia

Full list of author information is available at the end of the article
}

action, transcription, ion transport, neuromodulation, immunemodulation and apoptosis [3,4]. In particular, they play a fundamental role in normal functioning of immune system and proliferation of $\mathrm{T}$ cells and immunological defence $[5,6]$.

One particular species of interest; superoxide (O2-), is generated either by accidental result of incomplete electron transfers in the electron transport chain or by design in activated white blood cells with the function of destroying pathogens. Upon production, O2- molecules are rapidly metabolized into hydrogen peroxide $(\mathrm{H} 2 \mathrm{O} 2)$, which further helps in destroying some pathogens. Intermediate concentrations of $\mathrm{H} 2 \mathrm{O} 2$ (and certain other ROS) result in activation of nuclear factor $\kappa B(N F-\kappa B)$, and activating protein-1 (AP-1), which are transcription factors that up-regulate several antioxidant pathways. They are neutralized by the activity of key antioxidant genes such as Manganese, Magnesium or Copper Superoxide dismutase (Mn, $\mathrm{Mg}$ or $\mathrm{Cu}-\mathrm{SOD})$ [7].
C Biomed Central

(C) 2013 Paracha et al.; licensee BioMed Central Ltd. This is an Open Access article distributed under the terms of the Creative Commons Attribution License (http://creativecommons.org/licenses/by/2.0), which permits unrestricted use, distribution, and reproduction in any medium, provided the original work is properly cited. 


\section{ROS and oxidative stress}

ROS are usually produced during the processes of aerobic metabolism, ongoing stress, and exposure to UV light or $\mathrm{X}$-rays. They play an important role in many of the signaling reactions in different organisms from bacteria to mammalian cells. These were previously considered as only the toxic by-products but now they are also known to work in complex signaling network of cells [8].

Many different enzymes in mitochondria, endoplasmic reticulum, peroxisomes and other cell compartments are involved in synthesis of ROS $[9,10]$ that causes cellular stress either through direct interaction with the biological molecules such as proteins, lipids and nucleic acids, or through activation of classical signaling cascades involved in stress responses including protein kinases, cytokines, and transcription factors $[8,11]$ leading to inflammatory responses.

\section{Role of mitochondria and endoplasmic reticulum in oxidative stress}

Mitochondria generate ROS as a by-product of ATP synthesis via oxidative phosphorylation that may cause oxidative injury to mitochondrial DNA (mtDNA) $[12,13]$. Different oxidative stress conditions usually result in various diseases associated with alteration or depletion of mtDNA copy numbers [14-17].

$\mathrm{HCV}$ also changes the steady-state levels of a mitochondrial protein chaperone, referred to as prohibitin, that disturbs the mitochondrial respiratory chain leading to overproduction of ROS [18].

Endoplasmic reticulum (ER) is an organelle in the cells that is responsible for folding of proteins. Researchers are of the opinion that protein oxidation in ER results in protein folding and production of ROS that results in oxidative stress. ER is also the primary storage site for calcium that is required for protein folding reactions [19]. Researchers reported that oxidative stress may result in elevated leakage of calcium from ER lumen and the same thing happens in ER stress [20-22]. As more calcium comes in cytosol, mitochondrial ROS production increases [19].

\section{Role of hepatitis C virus (HCV) in oxidative stress}

Hepatitis $\mathrm{C}$ virus (HCV) belongs to Flaviviridae family of RNA viruses having positive strand RNA genome [23] of approximately $9400 \mathrm{bp}$ in length [24]. HCV results in 34 million new cases of viral hepatitis annually. Nearly 150 million people are chronically infected having a risk of liver cirrhosis and/or liver cancer [25]. In the mid 1990s, researchers found the occurrence of oxidative stress during chronic hepatitis C [26].

Although viral replication mostly takes place in the hepatocytes but HCV potentially attacks the cells of the immune system and propagates there. In this case, lymphocytes are found to be involved in the occult - occult HCV infection $(\mathrm{OHCI})$ - and active forms of disease. OHCI causes phosphoinositol 3-kinase-mediated cellular response in peripheral blood lymphocytes after mitochondrial oxidative stress and damage to DNA double strands. OHCI has been found to be related to increased risk of developing hepatocellular carcinoma and lymphoproliferative disorders [27].

Researchers reported that in chronic hepatitis, immunity initiates the production of ROS [28] and nitric oxide (NO) [29]. This was further reported by Farinati et al. that $\mathrm{HCV}$ produces more ROS than other hepatitis viruses [30] and patients with chronic hepatitis $\mathrm{C}$ have over $80 \%$ chances of developing chronic diseases $(\mathrm{CHC})$ as compared to patients of hepatitis A, B and E [31]. An increase in the amount of ROS by two to five orders of magnitude in liver tissue from $\mathrm{CHC}$ patients have also been reported $[32,33]$ and significant increase in lymphocytes of patients with chronic and OHCI [27].

$\mathrm{HCV}$ replicates in cytoplasm and results in chronic infections that may finally cause chronic hepatitis, cirrhosis, and hepatocellular carcinoma (HCC) [34,35]. The extent of mitochondrial injury and severity of oxidative injury exerted in liver tissue represent severity of $\mathrm{HCV}$ infection [36]. Oxidative stress has also been found to play an important role in HCV genome translation that is found to be mediated via PERK-mediated inhibition of cap-dependent translation [26]. Previously researchers found that ROS induced viral genome heterogeneity is the probable mechanism for viral escape from the immune system [37].

\section{$H C V$ proteins associated with oxidative stress}

$\mathrm{HCV}$ viral nucleocapsid protein, an HCV core protein, has been found to increase the oxidative stress in liver [38]. Out of 10 viral proteins, the core protein is the strongest regulator $[39,40]$ but is not the only one associated with increased oxidative stress as NS3, or NS5A proteins have also been found to increase the oxidative stress [41-43]. In further studies, researchers found that E1 [39], E2 [29,44], and NS4B [39,45] are also involved in oxidative stress.

The nonstructural protein 5A (NS5A), which is an integral membrane protein important for replication of virus along with other important phenomenon such as interferon resistance, and apoptosis [46], encoded by human HCV RNA genome, changes the calcium levels. The core, NS5A, and NS3 proteins not only increase calcium uptake by mitochondria but also cause oxidation of mitochondrial glutathione leading to increased ROS $[13,47,48]$ in mitochondria resulting in translocation of NF- $\mathrm{kB}$ and STAT-3 transcription factors into the nucleus leading to oxidative stress. Antioxidants remove NS5A-induced activation of NF- $\mathrm{kB}$ and STAT-3 $[49,50]$. NS4B also increases the translocation of NF- $\mathrm{kB}$ into the nucleus through protein- 
tyrosine kinase (PTK) mediated phosphorylation and subsequent degradation of $\kappa \mathrm{B}$ alpha [45]. Basic points of viral proteins involved in oxidative stress are mentioned in the Table 1.

NS5A protein has also been found to play an important role in activation of p38 MAPK (mitogen-activated protein kinase), JNK (c-Jun N-terminal kinase) and AP-1 (activator protein-1) that are linked to increased oxidative stress leading to increased MnSOD (manganese-superoxide dismutase) antioxidant responses [1].

Along with ROS, NO also causes oxidative DNA damage. NO not only damages DNA but also inhibits DNA repair [51-53] as shown in Figure 1. The Casein kinase 2 and phosphoinositide- 3 kinase mediates the effect of core and NS5A proteins [39].

\section{Effect of HCV on the enzymes}

Research showed increased levels of some of the defense enzymes such as heme oxygenase (HO-1) [54] and thioredoxin (Trx) $[55,56]$ in patients of $\mathrm{CHC}$. $\mathrm{HCV}$ also poses danger to antioxidant systems in the body such as HO-1 and NADH dehydrogenase quinone 1 [18] that may lead to increased oxidative stress in liver during infections caused by HCV. In addition to these, researchers found decreased levels of many other antioxidant defense enzymes, such as manganese or $\mathrm{Cu} / \mathrm{Zn}$ superoxide dismutase (SOD), glutathione reductase, and glutathione peroxidase, in the peripheral blood mononuclear cells (PBMC) of the patients of $\mathrm{CHC}[27,57,58]$.

$\mathrm{HCV}$ induces the expression of $3 \beta$-hydroxysterol $\Delta 24$ reductase (DHCR24) as $5^{\prime}$-flanking genomic promoter region of DHCR24 is responsive to $\mathrm{HCV}$. This region also binds Sp1 transcription factor in response to oxidative stress under the regulation of ataxia telangiectasia mutated (ATM) kinase. Overexpression of DHCR24 decreases acetylation resulting in disturbed p53 activity leading to suppressed hydrogen peroxide-induced apoptotic response in hepatocytes [59].

HCV also acts as a regulator of Nox4, a member of the NADPH oxidase (Nox) family, inducing ROS production through autocrine transforming growth factor $\beta$ (TGF- $\beta$ )dependent mechanism [60]. ROS are found to have an important influence on development of inflammatory liver disease mediated by HCV $[61,62]$.

Table $1 \mathrm{HCV}$ proteins involved in oxidative stress

\begin{tabular}{|c|c|}
\hline HCV proteins & What they can do? \\
\hline \multirow{2}{*}{$\begin{array}{c}\text { Core protein, NS3, NS5A, } \\
\text { E1, E2, NS4B }\end{array}$} & - Increase oxidative stress \\
\hline & - Increase calcium uptake by mitochondria \\
\hline Core protein, NS5A, NS3 & $\begin{array}{l}\text { - Oxidation of mitochondrial glutathione } \\
\text { leading to elevated ROS }\end{array}$ \\
\hline
\end{tabular}

\section{Iron and the oxidative stress}

Iron has also been found to play an important role in oxidative stress. Fenton's reaction, which causes the conversion of low active $\mathrm{H} 2 \mathrm{O} 2$ into potential hydroxyl and peroxide radicals, helps iron ions in ROS production $[10,63]$. Iron is present in many parts of the body and liver is one of the main sites of storage [64-66], thereby increased iron ions could result in more oxidative stress in liver cells. Usually the concentration of iron in plasma in humans remain stable at $10-30 \mu \mathrm{M}$ [64] but nearly $40 \%$ of $\mathrm{CHC}$ patients showed elevated levels of iron and ferritin in serum and $10 \%$ of patients showed elevated levels of iron in liver [67]. Researchers found that phlebotomy or dietary iron restriction decreases oxidative stress and lipid peroxidation in $\mathrm{CHC}$ patients $[68,69]$.

\section{Protection}

Human body is specially developed to work against oxidative stress [70,71]. The defense system of the body consists of low molecular weight compounds such as glutathione and other antioxidants along with "phase II defense enzymes" that are capable of getting rid of ROS.

\section{Glutathione}

Glutathione is synthesized in all types of eukaryotic cells and especially found in liver. It is considered as one of the most important anti-oxidants. It is also a redox and cell signaling regulator, and works by decreasing $\mathrm{H} 2 \mathrm{O} 2$ level and by scavenging reactive oxygen and nitrogen radicals [72]. Researchers found decreased glutathione levels in a large number of CHC patients [26].

Recently, researchers have reported that glutathione, which is usually oxidized in oxidation stress to prevent cellular components from reactive oxygen species, moves towards vacuole by $\mathrm{ABC}-\mathrm{C}$ transporter Ycf1 rather than staying in the cytoplasm. This movement of the oxidized glutathione to the vacuole protects the cellular metabolic processes of cytoplasm from the oxidative damage. This finding also shows that the conventional methods of determining oxidative stress have to be re-evaluated as the cells could have been under oxidative stress even when the cytoplasm looks healthy [73].

Researchers found that a by-product of glutathione; $\mathrm{N}$-acetylcysteine (NAC), also decreases oxidative stress $[74,75]$. Some "Oxidative stress" related processes are presented in Figure 2.

\section{Nrf2}

A transcription factor protein, namely Nrf2, controls the cell's ability to cope with oxidative stress by elevating the expression of key genes for eliminating the damaged proteins. During elevated oxidative stress, Nrf2 increases the production of $20 \mathrm{~S}$ proteasome and also affects the $\mathrm{Pa} 28 \alpha \beta(11 \mathrm{~S})$ proteasome regulator ( $\mathrm{Pa} 28)$ helping in 


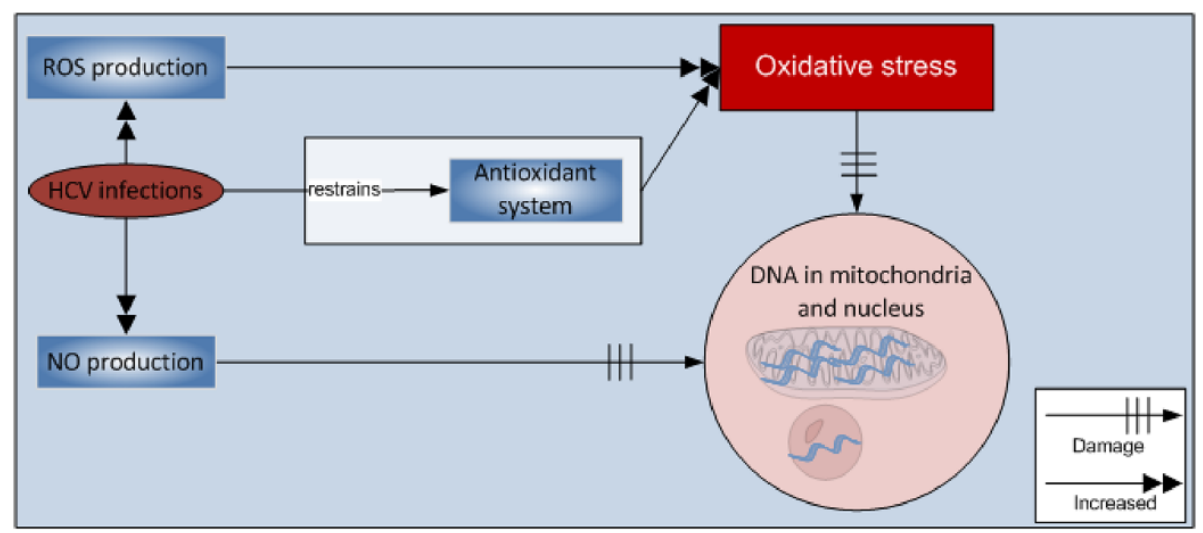

Figure $1 \mathrm{HCV}$ infection and DNA damage.

the breakdown of oxidized proteins that could destroy the cells after accumulation [76]. Nrf2 protein has also been found to be related to stem cell division [77]. In another study, this protein has been found to be related to the increased chances of atherosclerosis due to increased plasma cholesterol levels and the cholesterol content in liver [78]. It has been reported that activation of $\mathrm{Nrf2}$, as a result of $\mathrm{HCV}$, is mediated by the mitogen- activated protein (MAP) kinases p38 MAPK and janus kinase [79].

The antioxidant defense Nrf2/ARE pathway is mediated by five viral proteins, i.e., core, E1, E2, NS4B, and NS5A. The core protein is found to be the most potent regulator [80]. However, in another contradictory study, researchers found the suppressed Nrf2/ARE pathway in the HCVcC system [81]. The reasons for this contradiction are not

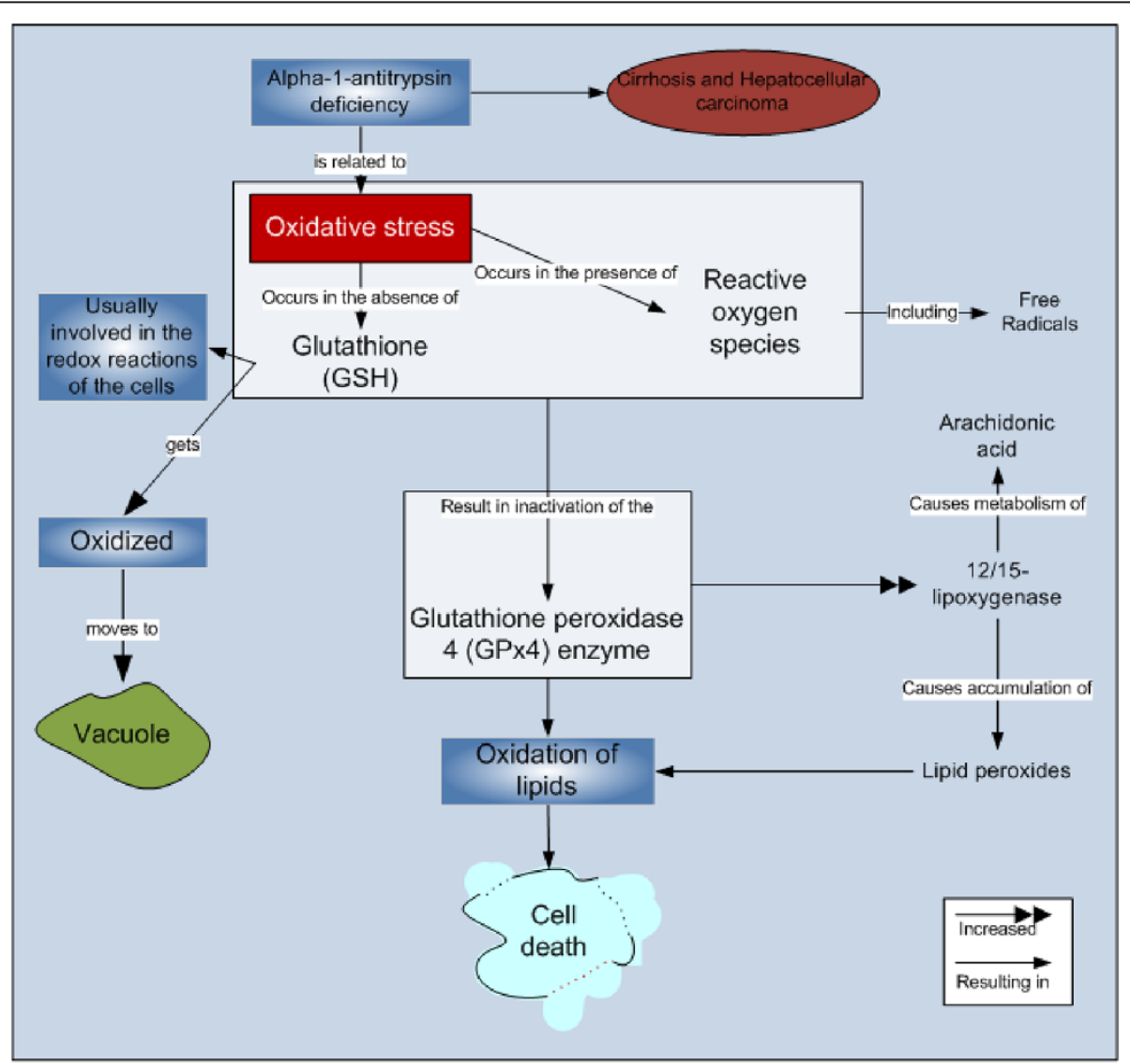

Figure 2 Oxidative stress related processes. 
known although the researchers used the similar infection conditions.

\section{MDA and complement factor $\mathrm{H}$}

The lipids in cell membranes produce many of the reactive products upon oxidative stress. One of those compounds is malondialdehyde (MDA) that changes other molecules to produce novel oxidation-specific epitopes that takes the attention and inflammatory reaction of the innate immune system. MDA is also found to attract an immune system protein called complement factor $\mathrm{H}(\mathrm{CFH})$ that stops the uptake of MDA-modified proteins by macrophages after binding to MDA. This resulted in neutralization of inflammatory effects of MDA in mice model [82]. Presently known mechanisms of $\mathrm{Nrf} 2$ and Complement Factor $\mathrm{H}$ are presented in the Figure 3.

\section{HNF and MRP2}

Qadri et al. reported that HCV induces the hepatocyte nuclear factor (HNF)-1 and HNF4, and this process has been attributed to the elevated oxidative stress as well as the direct interaction of NS5A protein and HNF1. Both HNF1 and HNF4 are considered as the important transcriptional factors for the normal development of the liver. This HNF1 activation results in increased MRP (multidrug resistance protein)-2 activity that plays an important role in the detoxification process associated with oxidative stress [83].

\section{PARP1 and SIRT6}

A protein, sirtuin 6 (SIRT6), is produced maximally under oxidative stress. This protein along with poly [adenosine diphosphate (ADP)-ribose] polymerase 1 (PARP1) protein helps in repair of double strand breaks. PARP1 is an enzyme that is among the first compounds responding to DNA damage. SIRT6 is helpful in DNA repair even in the absence of oxidative stress. Researchers found that increased levels of SIRT6 help in more rapid direction of the DNA repair enzymes towards the sites of damage thereby increase the restoration of double strand breaks [84]. The role of prohibitin and SIRT6 are presented in the Figure 4.

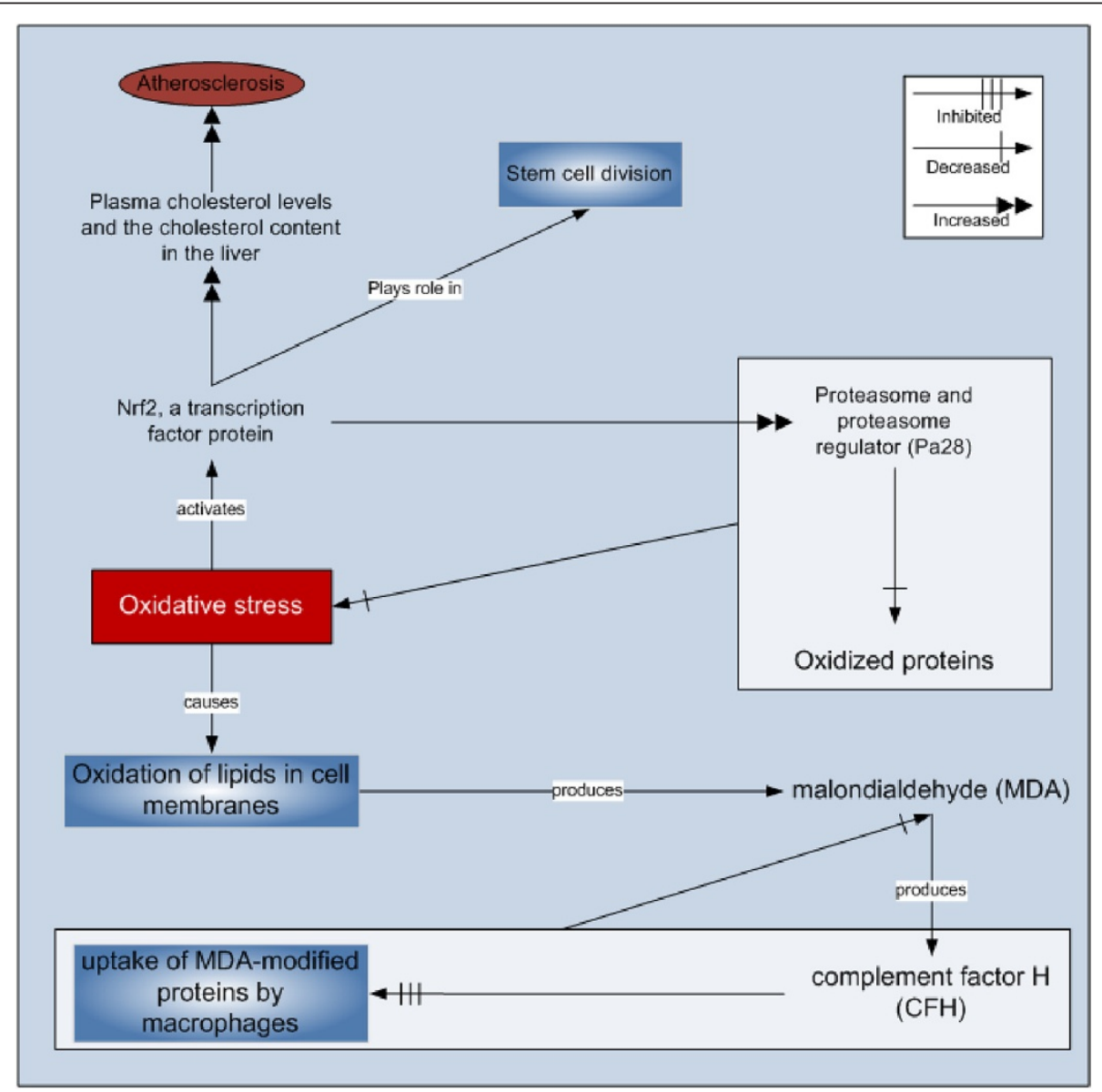

Figure 3 Oxidative stress and self-defense mechanisms. 


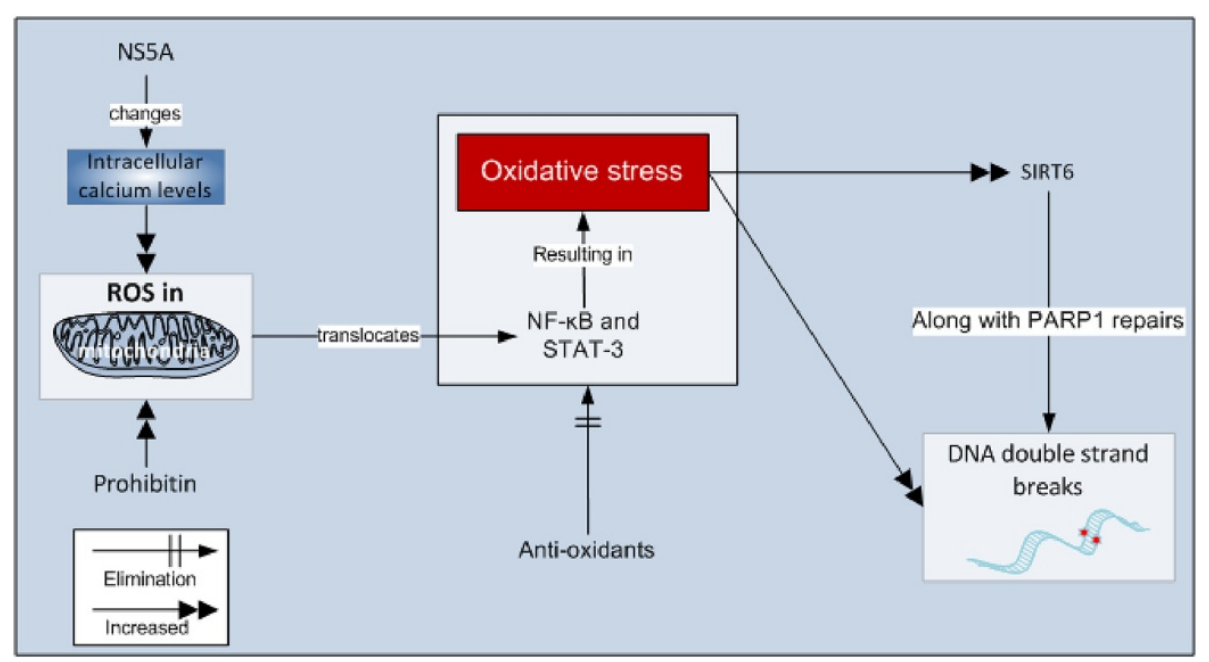

Figure 4 Role of prohibitin and SIRT6 in oxidative stress.

\section{Future directions}

There is no doubt that oxidative stress plays an important role in $\mathrm{HCV}$ pathogenesis, therefore the combination of several mechanisms described above could be exploited to reach the new solutions of combating the oxidative stress in HCV infection. Antioxidants may be employed in 4 different ways 1) to impair in HCV replication 2) to improve liver enzyme levels, 3) to protect against liver cell damage and 4) to render interferon anti-viral therapy more effective. In fact, triple antioxidants therapies are on rise, which include such as alpha-lipoic acid, silymarin and selenium in suppressing HCV-induced liver disease [85], when used together with Vitamins $C$ and $E$, and in a healthy diet and exercise regime [86]. Hypolipidemic agent, nordihydroguairetic acid which is also a potential antioxidant has been shown to affect lipid droplet morphology and HCV propagation [87]. MnSOD are shown to be the prime candidates for reversal of HCV-induced fibrosis [88] and activation of NFkB may be another way to boost antioxidant MnSOD response [89]. In a phase II study of HCV patients, the mitochondria-targeted anti-oxidant mitoquinone is shown to decrease liver damage [90].

Researchers showed that peripheral blood leukocyte mtDNA copy number and oxidative stress could help in assessment of mitochondrial damage in $\mathrm{HCV}$-infected patients but it needs further work, whether they can be utilized to evaluate the activity or severity of the HCVrelated liver diseases. The clinical significance of damage to mtDNA between the occult and overt HCV-infected patients needs further research. Moreover, the changes in mtDNA damage with time in different HCV-infected patients and the risk of consequent hepatocellular carcinoma needs further studies [13]. Role of oxidative stress on HCV entry and particle assembly and release needs more research in which $\mathrm{HCV}$ cell entry is thought to be a multi-step process [91].

Another important thing that needs further research is the role of antioxidant defense systems against HCV as researchers found some contradictory results such as in the case of antioxidant Defense Nrf2/ARE Pathway [26]. Oxidative stress, in mouse model, has also been found to be related to the expression of misfolded human alpha-1antitrypsin mutant $\mathrm{Z}$ protein but the mechanism, which can be more than one, are still not clear. Moreover, the effects of different levels of monomer, non-globular polymer or globular forms on oxidative stress need further research [92].

\section{Abbreviations}

AIF: Apoptosis inducing factor; AP-1: Activator protein-1; ARE: antioxidant response elements; ATM: Ataxia telangiectasia mutated; ATP: Adenosine triphosphate; CHF: Complement factor H; DHCR24: 3 $\beta$-hydroxysterol $\Delta 24-$ reductase; ER: Endoplasmic reticulum; GSH: Glutathione; HCC: Hepatocellular carcinoma; HCV: Hepatitis C virus; HNF: Hepatocyte nuclear factor; HO: Heme oxygenase; JNK: c-Jun N-terminal kinase; MDA: Malondialdehyde;

MnSOD: manganese-superoxide dismutase; MRP: Multidrug resistance protein; mtDNA: mitochondrial DNA; NO: Nitric oxide; Nox: NADPH oxidase; NS5A: Nonstructural protein 5A; OHCl: occult HCV infection; p38 MAPK: mitogen-activated protein kinase; PARP1: Poly[adenosine diphosphate (ADP)-ribose] polymerase 1; PBMC: peripheral blood mononuclear cells; PERK: PKR-like endoplasmic reticulum kinase; PTK: Protein-tyrosine kinase; RNS: Reactive Nitrogen Species; ROS: Reactive oxygen species; SIRT: Sirtuin; SOD: Superoxide dismutase; TGF- $\beta$ : Transforming growth factor $\beta$; Trx: Thioredoxin.

\section{Competing interests}

The authors declare that they have no competing interests.

\section{Authors' contributions}

UZP and KF reviewed the literature, and wrote the manuscript. IQ critically reviewed and edited the manuscript. AA, AC, GD and MA helped UZP and $\mathrm{KF}$ in literature review. All the authors read and approved the final manuscript. 


\section{Acknowledgements}

UZP and KF were supported from seed funds provided by NGO Mairaj Foundation. Financial support to AA, AC, MA and IQ was provided by the King Fahd Medical Research Center, king Abdul Aziz University, Jeddah and additional support was provided to AC, MA, GD and AA from the King Abdullah City of Science and Technology (KACST). IQ and MA also received funds from the Center of Excellence in genomic Medicine (CEGM).

\section{Author details}

${ }^{1}$ Department of Pharmaceutics, Hajvery University, Lahore, Pakistan. ${ }^{2} \mathrm{IQ}$ Institute of Infection and Immunity, Lahore, Punjab, Pakistan. ${ }^{3}$ Center of Excellence in Genomic Medicine, King Abdul Aziz University, PO Box 80216, Jeddah 21589, Saudi Arabia. ${ }^{4}$ Faculty of Applied Medical Sciences, King Abdulaziz University, PO Box 80216, Jeddah 21589, Saudi Arabia. ${ }^{5}$ King Fahd Medical Research Center, King Abdul Aziz University, PO Box 80216, Jeddah 21589, Saudi Arabia.

Received: 12 June 2013 Accepted: 31 July 2013

Published: 7 August 2013

\section{References}

1. Qadri I, Iwahashi M, Capasso JM, Hopken MW, Flores S, Schaack J, Simon FR: Induced oxidative stress and activated expression of manganese superoxide dismutase during hepatitis C virus replication: role of JNK, p38 MAPK and AP-1. Biochem J 2004, 378(Pt 3):919-928.

2. Jones DP: Redefining oxidative stress. Antioxid Redox Signal 2006, 8(9-10):1865-1879.

3. Gloire G, Legrand-Poels S, Piette J: NF-kappaB activation by reactive oxygen species: fifteen years later. Biochem Pharmacol 2006, 72(11):1493-1505.

4. Lander HM: An essential role for free radicals and derived species in signal transduction. FASEB J 1997, 11(2):118-124.

5. Devadas S, Zaritskaya L, Rhee SG, Oberley L, Williams MS: Discrete generation of superoxide and hydrogen peroxide by $T$ cell receptor stimulation: selective regulation of mitogen-activated protein kinase activation and fas ligand expression. J Exp Med 2002, 195(1):59-70.

6. Hildeman DA: Regulation of T-cell apoptosis by reactive oxygen species. Free Radic Biol Med 2004, 36(12):1496-1504.

7. Sen $\mathrm{CK}$, Sies $\mathrm{H}$, Baeuerle PA: Antioxidant and redox regulation of genes. Academic Press 2000

8. Mittler R, Vanderauwera S, Suzuki N, Miller G, Tognetti VB, Vandepoele K, Gollery M, Shulaev V, Van Breusegem F: ROS signaling: the new wave? Trends Plant Sci 2011, 16(6):300-309.

9. Go YM, Jones DP: Redox compartmentalization in eukaryotic cells. Biochim Biophys Acta 2008, 1780(11):1273-1290.

10. Ryter SW, Kim HP, Hoetzel A, Park JW, Nakahira K, Wang X, Choi AM: Mechanisms of cell death in oxidative stress. Antioxid Redox Signal 2007, 9(1):49-89.

11. Desikan R, Hancock J, Neill S: Reactive Oxygen Species as Signalling Molecules. In Antioxidants and Reactive Oxygen Species in Plants. Oxford, UK: Blackwell Publishing Ltd; 2007:169-196.

12. Yamada S, Nomoto S, Fujii T, Kaneko T, Takeda S, Inoue S, Kanazumi N, Nakao A: Correlation between copy number of mitochondrial DNA and clinico-pathologic parameters of hepatocellular carcinoma. Eur J Surg Oncol 2006, 32(3):303-307.

13. Yen HH, Shih KL, Lin TT, Su WW, Soon MS, Liu CS: Decreased mitochondrial deoxyribonucleic acid and increased oxidative damage in chronic hepatitis C. World J Gastroenterol 2012, 18(36):5084-5089.

14. Okochi O, Hibi K, Uemura T, Inoue S, Takeda S, Kaneko T, Nakao A: Detection of mitochondrial DNA alterations in the serum of hepatocellular carcinoma patients. Clin Cancer Res 2002, 8(9):2875-2878.

15. Liu CS, Tsai CS, Kuo CL, Chen HW, Lii CK, Ma YS, Wei YH: Oxidative stressrelated alteration of the copy number of mitochondrial DNA in human leukocytes. Free Radic Res 2003, 37(12):1307-1317.

16. Kim JY, Hwang JM, Ko HS, Seong MW, Park BJ, Park SS: Mitochondrial DNA content is decreased in autosomal dominant optic atrophy. Neurology 2005, 64(6):966-972.

17. De Mendoza C, Soriano V: The role of hepatitis $\mathrm{C}$ virus (HCV) in mitochondrial DNA damage in HIV/HCV-coinfected individuals. Antivir Ther 2005, 10(Suppl 2):M109-M115.
18. Fujinaga $H$, Tsutsumi $T$, Yotsuyanagi H, Moriya K, Koike K: Hepatocarcinogenesis in hepatitis C: HCV shrewdly exacerbates oxidative stress by modulating both production and scavenging of reactive oxygen species. Oncology 2011, 81(Suppl 1):11-17.

19. Malhotra JD, Kaufman RJ: Endoplasmic reticulum stress and oxidative stress: a vicious cycle or a double-edged sword? Antioxid Redox Signal 2007, 9(12):2277-2293.

20. Berridge MJ, Bootman MD, Roderick HL: Calcium signalling: dynamics, homeostasis and remodelling. Nat Rev Mol Cell Biol 2003, 4(7):517-529.

21. Görlach A, Klappa P, Kietzmann T: The endoplasmic reticulum: folding, calcium homeostasis, signaling, and redox control. Antioxid Redox Signal 2006, 8(9-10):1391-1418.

22. Lizák B, Czegle I, Csala M, Benedetti A, Mandl J, Bánhegyi G: Translocon pores in the endoplasmic reticulum are permeable to small anions. Am J Physiol Cell Physiol 2006, 291(3):C511-C517.

23. Choo QL, Kuo G, Weiner AJ, Overby LR, Bradley DW, Houghton M: Isolation of a cDNA clone derived from a blood-borne non-A, non-B viral hepatitis genome. Science 1989, 244(4902):359-362.

24. Simmonds P: Genetic diversity and evolution of hepatitis C virus--15 years on. J Gen Virol 2004, 85(Pt11):3173-3188.

25. WHO: Hepatitis C. http://www.who.int/mediacentre/factsheets/fs164/en/.

26. Ivanov AV, Bartosch B, Smirnova OA, Isaguliants MG, Kochetkov SN: HCV and Oxidative Stress in the Liver. Viruses 2013, 5(2):439-469.

27. Bhargava A, Raghuram GV, Pathak N, Varshney S, Jatawa SK, Jain D, Mishra PK: Occult hepatitis $C$ virus elicits mitochondrial oxidative stress in lymphocytes and triggers PI3-kinase-mediated DNA damage response. Free Radic Biol Med 2011, 51(9):1806-1814.

28. Muriel P: Role of free radicals in liver diseases. Hepatol Int 2009, 3(4):526-536.

29. García-Monzón C, Majano PL, Zubia I, Sanz P, Apolinario A, Moreno-Otero R: Intrahepatic accumulation of nitrotyrosine in chronic viral hepatitis is associated with histological severity of liver disease. J Hepatol 2000, 32(2):331-338

30. Farinati F, Cardin R, De Maria N, Della Libera G, Marafin C, Lecis E, Burra P, Floreani A, Cecchetto A, Naccarato R: Iron storage, lipid peroxidation and glutathione turnover in chronic anti-HCV positive hepatitis. $J$ Hepatol 1995, 22(4):449-456.

31. Rosen HR, Gretch DR: Hepatitis C virus: current understanding and prospects for future therapies. Mol Med Today 1999, 5(9):393-399.

32. Valgimigli $M$, Valgimigli L, Trerè $D$, Gaiani S, Pedulli GF, Gramantieri L, Bolondi L: Oxidative stress EPR measurement in human liver by radicalprobe technique. Correlation with etiology, histology and cell proliferation. Free Radic Res 2002, 36(9):939-948.

33. Valgimigli L, Valgimigli M, Gaiani S, Pedulli GF, Bolondi L: Measurement of oxidative stress in human liver by EPR spin-probe technique. Free Radic Res 2000, 33(2):167-178.

34. Jenny-Avital ER: Hepatitis C. Curr Opin Infect Dis 1998, 11(3):293-299.

35. Saito I, Miyamura T, Ohbayashi A, Harada H, Katayama T, Kikuchi S, Watanabe Y, Koi S, Onji M, Ohta Y, et al: Hepatitis C virus infection is associated with the development of hepatocellular carcinoma. Proc Natl Acad Sci U S A 1990, 87(17):6547-6549.

36. Barbaro G, Di Lorenzo G, Asti A, Ribersani M, Belloni G, Grisorio B, Filice G, Barbarini G: Hepatocellular mitochondrial alterations in patients with chronic hepatitis C: ultrastructural and biochemical findings. Am J Gastroenterol 1999, 94(8):2198-2205.

37. Forns X, Purcell RH, Bukh J: Quasispecies in viral persistence and pathogenesis of hepatitis C virus. Trends Microbiol 1999, 7(10):402-410.

38. Koike $\mathrm{K}$ : Hepatitis $\mathrm{C}$ virus contributes to hepatocarcinogenesis by modulating metabolic and intracellular signaling pathways. J Gastroenterol Hepatol 2007, 22(Suppl 1):S108-S111.

39. Ivanov AV, Smirnova OA, Ivanova ON, Masalova OV, Kochetkov SN, Isaguliants MG: Hepatitis C virus proteins activate NRF2/ARE pathway by distinct ROS-dependent and independent mechanisms in HUH7 cells. PLoS One 2011, 6(9):e24957.

40. Pal S, Polyak SJ, Bano N, Qiu WC, Carithers RL, Shuhart M, Gretch DR, Das A Hepatitis $C$ virus induces oxidative stress, DNA damage and modulates the DNA repair enzyme NEIL1. J Gastroenterol Hepatol 2010, 25(3):627-634.

41. Bureau C, Bernad J, Chaouche N, Orfila C, Béraud M, Gonindard C, Alric L, Vinel JP, Pipy B: Nonstructural 3 protein of hepatitis $C$ virus triggers an oxidative burst in human monocytes via activation of NADPH oxidase. J Biol Chem 2001, 276(25):23077-23083. 
42. García-Mediavilla MV, Sánchez-Campos S, González-Pérez P, Gómez-Gonzalo M, Majano PL, López-Cabrera M, Clemente G, García-Monzón C, GonzálezGallego J: Differential contribution of hepatitis C virus NS5A and core proteins to the induction of oxidative and nitrosative stress in human hepatocyte-derived cells. J Hepatol 2005, 43(4):606-613.

43. Thorén F, Romero A, Lindh M, Dahlgren C, Hellstrand K: A hepatitis C virusencoded, nonstructural protein (NS3) triggers dysfunction and apoptosis in lymphocytes: role of NADPH oxidase-derived oxygen radicals. J Leukoc Biol 2004, 76(6):1180-1186.

44. Ming-Ju H, Yih-Shou H, Tzy-Yen C, Hui-Ling C: Hepatitis C virus E2 protein induce reactive oxygen species (ROS)-related fibrogenesis in the HSC-T6 hepatic stellate cell line. J Cell Biochem 2011, 112(1):233-243.

45. Li S, Ye L, Yu X, Xu B, Li K, Zhu X, Liu H, Wu X, Kong L: Hepatitis C virus NS4B induces unfolded protein response and endoplasmic reticulum overload response-dependent NF-kappaB activation. Virology 2009, 391(2):257-264.

46. Liang $\mathrm{Y}$, Ye $\mathrm{H}$, Kang $\mathrm{CB}$, Yoon HS: Domain 2 of Nonstructural Protein $5 \mathrm{~A}$ (NS5A) of Hepatitis C Virus Is Natively Unfolded. Biochemistry 2007, 46(41):11550-11558.

47. Piccoli C, Quarato G, Ripoli M, D'Aprile A, Scrima R, Cela O, Boffoli D, Moradpour D, Capitanio N: Review HCV infection induces mitochondrial bioenergetic unbalance: causes and effects. Biochim Biophys Acta 2009, 1787(5):539-546.

48. Piccoli C, Scrima R, D'Aprile A, Ripoli M, Lecce L, Boffoli D, Capitanio N: Review Mitochondrial dysfunction in hepatitis $C$ virus infection. Biochim Biophys Acta 2006, 1757(9-10):1429-1437.

49. Gong G, Waris $G$, Tanveer $R$, Siddiqui A: Human hepatitis $C$ virus NS5A protein alters intracellular calcium levels, induces oxidative stress, and activates STAT-3 and NF-kB. Proc Natl Acad Sci U S A 2001, 98(17):9599-9604.

50. Okuda M, Li K, Beard MR, Showalter LA, Scholle F, Lemon SM, Weinman SA Mitochondrial injury, oxidative stress, and antioxidant gene expression are induced by hepatitis C virus core protein. Gastroenterology 2002, 122(2):366-375.

51. Jaiswal M, LaRusso NF, Shapiro RA, Billiar TR, Gores GJ: Nitric oxidemediated inhibition of DNA repair potentiates oxidative DNA damage in cholangiocytes. Gastroenterology 2001, 120(1):190-199.

52. Machida K, McNamara G, Cheng KT, Huang J, Wang CH, Comai L, Ou JH, Lai MM: Hepatitis $C$ virus inhibits DNA damage repair through reactive oxygen and nitrogen species and by interfering with the ATM-NBS /Mre11/Rad50 DNA repair pathway in monocytes and hepatocytes. J Immunol 2010, 185(11):6985-6998.

53. Machida K, Tsukamoto H, Liu JC, Han YP, Govindarajan S, Lai MM, Akira S, Ou JH: c-Jun mediates hepatitis $\mathrm{C}$ virus hepatocarcinogenesis through signal transducer and activator of transcription 3 and nitric oxidedependent impairment of oxidative DNA repair. Hepatology 2010, 52(2):480-492

54. Zhu Z, Wilson AT, Mathahs MM, Wen F, Brown KE, Luxon BA, Schmidt WN: Heme oxygenase- 1 suppresses hepatitis $C$ virus replication and increases resistance of hepatocytes to oxidant injury. Hepatology 2008, 48(5):1430-1439.

55. Sumida Y, Nakashima T, Yoh T, Nakajima Y, Ishikawa H, Mitsuyoshi H, Sakamoto Y, Okanoue T, Kashima K, Nakamura H, Yodoi J: Serum thioredoxin levels as an indicator of oxidative stress in patients with hepatitis C virus infection. J Hepatol 2000, 33(4):616-622.

56. Nakashima T, Sumida $Y$, Yoh T, Kakisaka $Y$, Nakajima $Y$, Ishikawa $H$, Mitsuyoshi H, Kashima K, Nakamura H, Yodoi J: Thioredoxin levels in the sera of untreated viral hepatitis patients and those treated with glycyrrhizin or ursodeoxycholic acid. Antioxid Redox Signal 2000, 2(4):687-694.

57. Levent G, Ali A, Ahmet A, Polat EC, Aytaç C, Ayşe E, Ahmet S: Oxidative stress and antioxidant defense in patients with chronic hepatitis $C$ patients before and after pegylated interferon alfa-2b plus ribavirin therapy. J Transl Med 2006, 4:25.

58. Osman HG, Gabr OM, Lotfy S, Gabr S: Serum levels of bcl-2 and cellular oxidative stress in patients with viral hepatitis. Indian J Med Microbiol 2007, 25(4):323-329.

59. Tsukiyama-Kohara K: Role of Oxidative Stress in Hepatocarcinogenesis Induced by Hepatitis C Virus. Int J Mol Sci 2012, 13(11):15271-15278.

60. Boudreau HE, Emerson SU, Korzeniowska A, Jendrysik MA, Leto TL: Hepatitis $\mathrm{C}$ virus $(\mathrm{HCV})$ proteins induce $\mathrm{NADPH}$ oxidase 4 expression in a transforming growth factor beta-dependent manner: a new contributor to HCV-induced oxidative stress. J Virol 2009, 83(24):12934-12946.

61. Choi J, Ou JH: Review Mechanisms of liver injury. III. Oxidative stress in the pathogenesis of hepatitis C virus. Am J Physiol Gastrointest Liver Physiol 2006, 290(5):G847-G851.

62. Jain SK, Pemberton PW, Smith A, McMahon RF, Burrows PC, Aboutwerat A, Warnes TW: Oxidative stress in chronic hepatitis C: not just a feature of late stage disease. J Hepatol 2002, 36(6):805-811.

63. Weinreb O, Amit T, Mandel S, Kupershmidt L, Youdim MB: Neuroprotective multifunctional iron chelators: from redox-sensitive process to novel therapeutic opportunities. Antioxid Redox Signal 2010, 13(6):919-949.

64. Ganz T, Nemeth E: Hepcidin and iron homeostasis. Biochim Biophys Acta 2012, 1823(9):1434-1443

65. Andrews NC: Iron homeostasis: insights from genetics and animal models. Nat Rev Genet 2000, 1(3):208-217.

66. Pantopoulos K, Porwal SK, Tartakoff A, Devireddy L: Mechanisms of mammalian iron homeostasis. Biochemistry 2012, 51(29):5705-5724.

67. Riggio O, Montagnese F, Fiore P, Folino S, Giambartolomei S, Gandin C, Merli M, Quinti I, Violante N, Caroli S, Senofonte O, Capocaccia L: Iron overload in patients with chronic viral hepatitis: how common is it? Am J Gastroenterol 1997, 92(8):1298-1301.

68. Kaito M, Iwasa M, Kobayashi Y, Fujita N, Tanaka H, Gabazza EC, Adachi Y, Kojima $Y$, Nakagawa N, Watanabe S: Iron reduction therapy by phlebotomy reduces lipid peroxidation and oxidative stress in patients with chronic hepatitis C. J Gastroenterol 2006, 41(9):921-922.

69. Fujita N, Horiike S, Sugimoto R, Tanaka H, Iwasa M, Kobayashi Y, Hasegawa K, Ma N, Kawanishi S, Adachi Y, Kaito M: Hepatic oxidative DNA damage correlates with iron overload in chronic hepatitis $C$ patients. Free Radic Biol Med 2007, 42(3):353-362

70. Smirnova OA, Ivanov AV, Ivanova ON, Valuev-Éllison VT, Kochetkov SN: Cellular defense systems against oxidative and ER stresses: mechanisms of regulation and influence of hepatitis C virus. Mol Biol (Mosk) 2011, 45(1):127-141

71. Aleksunes LM, Manautou JE: Emerging role of Nrf2 in protecting against hepatic and gastrointestinal disease. Toxicol Pathol 2007, 35(4):459-473.

72. Yuan L, Kaplowitz N: Glutathione in liver diseases and hepatotoxicity. Mol Aspects Med 2009, 30(1-2):29-41.

73. Morgan B, Ezerina D, Amoako TN, Riemer J, Seedorf M, Dick TP: Multiple glutathione disulfide removal pathways mediate cytosolic redox homeostasis. Nat Chem Biol 2012, 9(2):119-125.

74. Aggarwal A, Misro MM, Maheshwari A, Sehgal N, Nandan D: $\mathrm{N}$-acetylcysteine counteracts oxidative stress and prevents hCG-induced apoptosis in rat Leydig cells through down regulation of caspase-8 and JNK. Mol Reprod Dev 2010, 77(10):900-909.

75. Kerksick C, Willoughby D: The antioxidant role of glutathione and $\mathrm{N}$ acetyl-cysteine supplements and exercise-induced oxidative stress. J Int Soc Sports Nutr 2005, 2:38-44.

76. Pickering AM, Linder RA, Zhang H, Forman HJ, Davies KJ: Nrf2-dependent Induction of Proteasome and Pa28 Regulator Are Required for Adaptation to Oxidative Stress. J Biol Chem 2012, 287(13):10021-10031.

77. Hochmuth CE, Biteau B, Bohmann D, Jasper H: Redox Regulation by Keap1 and Nrf2 Controls Intestinal Stem Cell Proliferation in Drosophila. Cell Stem Cell 2011, 8(2):188-199.

78. Barajas B, Che N, Yin F, Rowshanrad A, Orozco LD, Gong KW, Wang X, Castellani LW, Reue K, Lusis AJ, Araujo JA: NF-E2-Related Factor 2 Promotes Atherosclerosis by Effects on Plasma Lipoproteins and Cholesterol Transport That Overshadow Antioxidant Protection. Arterioscler Thromb Vasc Biol 2011, 31(1):58-66.

79. Burdette $D$, Olivarez M, Waris G: Activation of transcription factor Nrf2 by hepatitis C virus induces the cell-survival pathway. J Gen Virol 2010, 91(Pt 3):681-690.

80. Kitada T, Seki S, Iwai S, Yamada T, Sakaguchi H, Wakasa K: In situ detection of oxidative DNA damage, 8-hydroxydeoxyguanosine, in chronic human liver disease. J Hepatol 2001, 35(5):613-618.

81. Carvajal-Yepes M, Himmelsbach K, Schaedler S, Ploen D, Krause J, Ludwig L, Weiss T, Klingel K, Hildt E: Hepatitis $C$ virus impairs the induction of cytoprotective Nrf2 target genes by delocalization of small Maf proteins. J Biol Chem 2011, 286(11):8941-8951.

82. Weismann D, Hartvigsen $K$, Lauer N, Bennett KL, Scholl HP, Charbel Issa P, Cano M, Brandstätter H, Tsimikas S, Skerka C, Superti-Furga G, Handa JT, Zipfel PF, Witztum JL, Binder CJ: Complement factor $\mathrm{H}$ binds 
malondialdehyde epitopes and protects from oxidative stress. Nature 2011, 478(7367):76-81.

83. Qadri I, Iwahashi M, Kullak-Ublick GA, Simon FR: Hepatocyte nuclear factor (HNF) 1 and HNF4 mediate hepatic multidrug resistance protein 2 upregulation during hepatitis C virus gene expression. Mol Pharmacol 2006, 70(2):627-636.

84. Mao Z, Hine C, Tian X, Van Meter M, Au M, Vaidya A, Seluanov A, Gorbunova V: SIRT6 Promotes DNA Repair Under Stress by Activating PARP1. Science 2011, 332(6036):1443-1446.

85. Berkson BM: A conservative triple antioxidant approach to the treatment of hepatitis C. Combination of alpha lipoic acid (thioctic acid), silymarin, and selenium: three case histories. Med Klin (Munich) 1999, 94:84-89.

86. Bilska A, Włodek L: Lipoic acid - the drug of the future? Pharmacol Rep 2005, 57(5):570-577.

87. Syed GH, Siddiqui A: Effects of hypolipidemic agent nordihydroguaiaretic acid on lipid droplets and hepatitis C virus. Hepatology 2011, 54(6):1936-1946

88. Emerit J, Samuel D, Pavio N: Cu-Zn super oxide dismutase as a potential antifibrotic drug for hepatitis $\mathrm{C}$ related fibrosis. Biomed Pharmacother 2006, 60(1):1-4.

89. Tai DI, Tsai SL, Chen YM, Chuang YL, Peng CY, Sheen IS, Yeh $C T$, Chang KS, Huang SN, Kuo GC, Liaw YF: Activation of nuclear factor kappaB in hepatitis $C$ virus infection: implications for pathogenesis and hepatocarcinogenesis. Hepatology 2000, 31(3):656-664

90. Gane EJ, Weilert F, Orr DW, Keogh GF, Gibson M, Lockhart MM, Frampton CM, Taylor KM, Smith RA, Murphy MP: The mitochondria-targeted antioxidant mitoquinone decreases liver damage in a phase II study of hepatitis C patients. Liver Int 2010, 30(7):1019-1026.

91. Bartosch B: HCV and Liver Carbohydrate Metabolism. In 7th Annual Meeting the New Visby University Network on Hepatitis C, Tartu, Estonia: February 20-23, 2010. Edited by Isaguliants MG. 2010.

92. Marcus NY, Blomenkamp K, Ahmad M, Teckman JH: Oxidative stress contributes to liver damage in a murine model of alpha-1-antitrypsin deficiency. Exp Biol Med (Maywood) 2012, 237(10):1163-1172.

doi:10.1186/1743-422X-10-251

Cite this article as: Paracha et al:: Oxidative stress and hepatitis $\mathrm{C}$ virus. Virology Journal 2013 10:251.

\section{Submit your next manuscript to BioMed Central and take full advantage of:}

- Convenient online submission

- Thorough peer review

- No space constraints or color figure charges

- Immediate publication on acceptance

- Inclusion in PubMed, CAS, Scopus and Google Scholar

- Research which is freely available for redistribution 